\title{
James Beattie and the Progress of Genius in the Aberdeen Enlightenment
}

\author{
RONNIE YOUNG
}

\begin{abstract}
James Beattie's The Minstrel is often viewed as a proto-Romantic work for its portrayal of the developing genius of Edwin. In this article I show how Beattie's exploration of genius also has a particular connection to the intellectual culture of the Aberdeen Enlightenment, which was responsible for producing leading works on genius during the late eighteenth century. This article examines the influence of Marischal College in shaping the analysis of genius during the period. It further demonstrates the impact of the Aberdeen Philosophical Society on Beattie's thought about genius as it appears in his verse and later critical writing.
\end{abstract}

Keywords: James Beattie, The Minstrel, genius, Scottish Enlightenment, Scottish Romanticism, Aberdeen University, Aberdeen Philosophical Society

It is generally recognised that James Beattie's poem The Minstrel had a significant influence on Romantic conceptions of poetic genius, particularly in supplying a model of autobiographical self-fashioning for William Wordsworth. ${ }^{\mathrm{I}}$ Although representing highly significant points of contact between the cultures of Enlightenment and Romanticism, such influences have instead often been read simply in terms of an embryonic Romanticism, in which critics project back into late eighteenth-century literary history the putative characteristics of the Romantic imagination in utero. As a result, Beattie the precursor has arguably overshadowed Beattie the poet, perhaps even to the same degree that Beattie the poet has been overshadowed by Beattie the philosopher. Dafydd Moore has suggested that critical focus on Beattie's work as prelude to The Prelude has, like critical focus on Ossian, 'too frequently [...] stood in for genuine engagement with these figures and their works in properly historicised terms'. ${ }^{2}$ In terms of Scottish Romanticism, the question of periodisation has been productive for probing the boundaries between Romanticism and the Scottish Enlightenment, ${ }^{3}$ and there has been some revival of interest in Beattie within this wider context, although not perhaps as much as one might expect given his critical foothold in both worlds. Murray Pittock has viewed The Minstrel as foreshadowing Romantic aesthetics through divorcing the bard figure from his communal role. While Beattie the precursor still figures, such a view resists the easy assimilation of Beattie into the history of English Romanticism by taking a more culturally nuanced approach to his transformation of bardic culture into Britishness. ${ }^{4}$ The recent rediscovery of Beattie's long-lost poem The Grotesquiad in Sir Walter Scott's library at Abbotsford, and associated work being carried out by Rhona Brown, should hopefully animate questions about Beattie's poetic reputation and Romantic readership of the poet. ${ }^{5}$ I recently argued that Beattie's work also formed part of a wider set of discourses on poetic genius which helped shape the initial critical reception of Robert Burns. ${ }^{6}$ True to the improperly historicising impulse of sketching poetic influence, I neglected here to explore the peculiar links between these discourses, specifically the way in which the key writers - James Macpherson, William Duff, 
JOBNAME: No Job Name PAGE: 2 SESS: 26 OUTPUT: Mon Sep 3 17:53:35 2012

/v2451/blackwell/journals/jecs_v0_i0/jecs_531

Alexander Gerard and Beattie himself - all had strong connections with Marischal College, Aberdeen, and more particularly how this nexus created a complex yet surprisingly localised context for the development of critical discourses on poetic genius.

In this article I examine the Aberdeen context for the analysis of genius. In it I attempt to show that, important links with British Romanticism notwithstanding, Beattie's Minstrel posits an intricate relationship between social progress, moral education, environment and the development of the individual poet that places him in the mainstream of Scottish Enlightenment thought. In the first section I outline the role of Marischal College as an influence on Beattie's exploration of genius and the manner in which The Minstrel echoes the concerns of Beattie's mentors and colleagues. In the second section I turn more specifically to the Aberdeen Philosophical Society as a formative context for Beattie's writing on genius. Here I look at the impact of the Society on both Beattie's verse and his later critical writing and, in particular, the influence of Alexander Gerard on The Minstrel and Beattie's Dissertations Moral and Critical (I783). This later work further reveals the evolution of Beattie's thought on genius and his engagement with key Enlightenment debates about the role of genius in society.

Beattie's The Minstrel (I77I-4) was, of course, subtitled 'the Progress of Genius'. This subtitle is both reflective of the interests of Aberdeen's literati and descriptive of the poem's attempt to trace the development of the poetic powers of a young minstrel, Edwin, over the course of two books. Book I, published in I77I, deals with Edwin's childhood and the flights of his untutored fancy during his solitary wanderings and as he reacts to the natural world around him. In Book II, published in I774, Edwin's genius progresses through a markedly different kind of experience, specifically his encounter with an old hermit who undertakes to teach him reason as a means of controlling his youthful passion and to introduce the young minstrel to the world. On the publication of the second book, Beattie wrote to Lord Hailes that his 'intention from the first was to give rather a philosophical or didactick than a narrative poem'. ${ }^{7}$ Accordingly, Beattie presents the reader with not so much a fable as a philosophical exploration of poetic development according to the factors used at the time in the analysis of genius. Such factors included natural ability, the right kinds of education, environment and the period in which the individual lives. In the kind of thought emanating from Aberdeen during the period the individual poetic genius is represented as not just the 'heaven-taught' recipient of god-given capacity but also as the beneficiary of such comparatively secular, and to some extent accidental, factors. In design, The Minstrel follows Aberdeen thought here as much as it pioneers later Romantic conceptions of imaginative creativity.

Beattie, however, does not directly acknowledge the influence of Aberdeen in The Minstrel. Instead, it could be argued that he places himself within a tradition of protoRomantic works by naming Thomas Percy's Reliques of Ancient English Poetry (I765) as his initial influence for the poem. In his original Advertisement to Book I (I77I) Beattie notes that 'The first hint of this performance was suggested by Mr PERCY's ingenious Essay on the English Minstrels, prefixed to his first volume of RELIQUES OF ANCIENT ENGLISH POETRY. ${ }^{8}$ Beattie also refers to the minstrel as 'a character which, according to the notions of our forefathers, was not only respectable, but sacred' (p.v) - a further allusion to Percy's rehabilitation of the minstrel as a respectable representative of national genius. ${ }^{9}$ Beattie thus appears to adopt from Percy a dignified cross-border figure who helps to 
JOBNAME: No Job Name PAGE: 3 SESS: 26 OUTPUT: Mon Sep 3 17:53:35 2012

/v2451/blackwell/journals/jecs_v0_i0/jecs_531

James Beattie and the Progress of Genius in the Aberdeen Enlightenment

consolidate the British state by giving that state an imaginative pedigree in the form of a Gothic tradition of poetic genius. However, The Minstrel pads out Percy's outline considerably with a psychological exploration of character which is more about the growth of the individual mind than about the development of national minstrelsy. Laura Bandiera has argued that The Minstrel, as 'primarily an artist's biography' which does not productively deploy the associations surrounding Percy's minstrel figure, 'owes virtually no debt' to Percy other than 'the title and perhaps the geographical framework'. ${ }^{\text {Io }}$ Percy's influence on the poem is not only more limited than Beattie himself suggests, confined as it is to such details as Beattie's decision to set his poem in the uncultivated past of Scotland, ${ }^{\mathrm{II}}$ but also leads us back to Aberdeen thought through its response to Aberdeen-educated James Macpherson. ${ }^{\mathrm{I} 2}$ As Phillip Connell points out, Percy's work sits in the context of rival literary histories provoked by the success of Ossian. While opposition to Ossian at this time was often political and part of the wider Scotophobia centred round Macpherson's patron, the third earl of Bute, Percy's response to Ossian is, as Connell argues, 'studiously diplomatic' in that it 'endeavour[s] to reconcile his Gothicist theories of English cultural identity with a Moderate, Butite agenda of Scottish cultural rapprochement'. ${ }^{\text {I3 }}$ Even beyond competing claims to Celtic and Gothic genealogy for the nation's poetry, there are conciliatory nods to Macpherson in Percy's work. His reference to minstrels as 'the genuine successors of ancient Bards' ${ }^{\mathrm{I}}{ }^{4}$ for example, shows him offering a historically more recent model of uncultivated genius contingent on the example of Ossian. The Reliques also present the poems and ballads collected 'not as labours of art, but as effusions of nature, shewing the first efforts of ancient genius', ${ }^{15}$ a statement that echoes Hugh Blair's reference to Macpherson's collection as the 'remains of ancient genius' in the Preface to Fragments of Ancient Poetry (I 760). ${ }^{16}$ In this respect it is Macpherson as much as Percy who can be seen to provide an immediate shaping context for Beattie's exploration of genius.

In addition to providing an influential model of bardic genius, the very concept of 'ancient genius' as defined by the Macpherson/Blair axis would ask new things of the polite reading public. Besides signalling that allowances should be made regarding taste in order to appreciate the poetry presented as the rude expressions of passion, the appreciation of original genius also demanded attention to the qualities of a special kind of "character'. Blair outlined the sentimental adjustments to be made to the character of genius in his Critical Dissertation on the Poems of Ossian (I763): 'Ossian, himself, appears to have been endowed by nature with an exquisite sensibility of heart; prone to that tender melancholy which is so often an attendant on great genius; and susceptible equally of strong and soft emotions.' ${ }^{\text {I7 }}$

This readerly adjustment from strict taste to sentimental reaction required by Ossian is also key to understanding The Minstrel's Gothic appeal and the character of Edwin. There we also see the kind of 'exquisite sensibility' and 'tender melancholy' that would appear to make Blair's outline of Ossian's qualities equally applicable to Edwin:

In truth he was a strange and wayward wight,

Fond of each gentle, and each dreadful scene.

In darkness, and in storm, he found delight:

Nor less, than when on ocean-wave serene

The southern sun diffused his dazzling shene.

Even sad vicissitude amused his soul:

And if a sigh would sometimes intervene,

And down his cheek a tear of pity roll,

A sigh, a tear, so sweet, he wish'd not to control. (I. 24) 
JOBNAME: No Job Name PAGE: 4 SESS: 26 OUTPUT: Mon Sep 3 17:53:35 2012

/v2451/blackwell/journals/jecs_v0_i0/jecs_531

4

RONNIE YOUNG

Beattie's appropriation of bardic tradition thus brought with it a degree of sentimental baggage, and Edwin's position as ancient 'man of feeling' echoed another influential association of primitive poetic genius with the leading traits of 'sensibility' in Blair's writing on Ossian.

If Ossian thus helped set the agenda for exploration of bardic genius in the I76os, this is not to say Beattie did not differ from Macpherson on point of primitive genius. On 29 March I762, for example, having read Macpherson's 'Fingal', Beattie wrote to Robert Arbuthnott that he remained 'insensible' to 'that part of its merit which exalts it, considered as a whole, above the Iliad or Aeneid and its author above Homer or Virgil', even if critics in London and Scotland currently 'aver Ossian to be a greater genius than either of these poets'. ${ }^{18}$ In an important recent exploration of the relations between Beattie and Macpherson, Dafydd Moore reminds us of further differences between the primitivist outlook of the two authors. Beattie's denunciation of modern luxury, for instance, contrasts with Macpherson's politicised primitivism and what Moore goes on to characterise as an anti-Hanoverian 'Jacobite rhetoric of commercial corruption'. Beattie also presents 'a more internalised primitivism' than Macpherson, which has less to do with the historicising approach to an earlier culture than with the 'development of the individual'. As Edwin develops, moreover, his pursuits are less active and more reflective than those depicted by Ossian. ${ }^{19}$ Yet even accepting their contrasting approaches to the primitive, there are striking similarities between Beattie and Macpherson, not least in their skilful transformation of a contemporary rhetoric of sensibility into a leading characteristic of ancient poetic genius, as outlined in the examples above. Both pit past in moral opposition to present yet shape that past according to the demands of contemporary aesthetic and philosophical discourse, and both present what Moore calls 'important syntheses of Scottish primitivist thinking'. ${ }^{20}$ As we shall see, Beattie's account of individual poetic development, as ahistorical as it may be, still synthesises the aesthetics of the sublime with the conjectural approach to genius and environment initiated at Aberdeen, and his views on education and moral development betray a similar influence.

Here the significance of Beattie and Macpherson's shared education becomes apparent. This education draws attention to a remarkable set of connections, centred on Marischal College, Aberdeen, which crucially link all leading Scottish authors on genius during the period. Macpherson was educated at Marischal College around I755. As Fiona Stafford suggests, this was an Aberdeen 'obsessed' with the 'idea of Original Genius' ${ }^{2 \mathrm{I}}$ It may be no coincidence that the leading works on genius to come out of the Scottish Enlightenment were produced within roughly a fifteen-year period by Church of Scotland ministers who had, like Macpherson, been educated mid-century at Marischal. These works include the two volumes by the Aberdeenshire minister William Duff, author of Essay on Original Genius (I767) and Critical Observations on the Writings of the Most Celebrated Original Geniuses in Poetry (I770), followed by Beattie's Minstrel itself and Alexander Gerard's Essay on Genius of I774. All three authors were at Marischal during roughly the same period. Gerard graduated MA in I744 but returned as substitute for David Fordyce in I750, the year Duff obtained his degree. ${ }^{22}$ Of closer connection were Beattie and Gerard. Beattie gained his degree in I753 and was taught by Gerard in his final year, by which time Gerard had replaced the now-deceased David Fordyce. In turn, Beattie succeeded Gerard in I760 as Professor of Moral Philosophy and Logic, after Gerard took up a new appointment as Professor in Divinity. ${ }^{23}$ Beattie was in turn elected member of the Aberdeen Philosophical Society on Gerard's recommendation. During this time significant institutional reforms and a modernisation of the arts curriculum occurred, but there were two individuals teaching at Marischal mid-century who are key to the study of genius in Aberdeen: David 
JOBNAME: No Job Name PAGE: 5 SESS: 26 OUTPUT: Mon Sep 3 17:53:35 2012

/v2451/blackwell/journals/jecs_v0_i0/jecs_531

James Beattie and the Progress of Genius in the Aberdeen Enlightenment

Fordyce, who taught the young Gerard, and Thomas Blackwell, under whom Beattie and Gerard studied and who was also a formative influence on Macpherson. ${ }^{24}$

The classical scholar Blackwell was Beattie's first professor and immediately recognised Beattie's merit, awarding him the prize of best scholar in I750. ${ }^{25}$ Blackwell, whom Joan Pittock has rightly termed a 'pioneer of primitivist thought', ${ }^{26}$ largely defined the terms by which genius would be understood in the Aberdeen Enlightenment through his Enquiry into the Life and Writings of Homer of I735 and its analysis of poetic genius according to such factors as the historical 'age' and environment in which the poet is nurtured. In this work Blackwell takes a secular view of genius, attributing Homer's pre-eminence to a fortunate confluence of natural causes and cultural factors:

Homer's poems are of Human Composition; inspired by no other Power than his own natural Faculties, and the Chances of his Education: In a word, That a Concourse of natural Causes, conspired to produce and cultivate that mighty Genius, and gave him the noblest Field to exercise it in, that ever fell to the share of a poet. ${ }^{27}$

Blackwell thus adopts a naturalistic approach which views genius according to the interplay between natural abilities and environment. For example, the climate and quality of soil in Homer's native land are said to 'inspire that Mildness of Temper, and Flow of Fancy, which favour the most extensive Views, and give the finest Conceptions of Nature and Truth' ${ }^{28}$ Furthermore, the 'State of the Country' in which the individual is bred and the manners and constitution of that country act as accidental causes which have a constitutive effect on individual character: 'they make us what we are, in so far as they reach our Sentiments, and give us a peculiar turn and appearance. ${ }^{29}$ If Homer has not been surpassed in some 2,700 years, as Blackwell's opening proposition suggests, the Bard's genius must be the product of conditions that are not only propitious but also antique. Homer is said to have written at a particular time when 'the Greek Language was brought to express all the best and bravest of the human Feelings, and retained a sufficient Quantity of its Original, amazing, metaphorick tincture' ${ }^{30}$ The Moderns, by contrast, live in a settled state which is regrettably unconducive to the epic muse. As Blackwell asserts, 'The Marvellous and Wonderful is the Nerve of the Epic Strain: But what marvellous Things happen in a well ordered State?'31

Blackwell's thought directly informed Scottish primitivism and the approach to genius adopted by such authors as Hugh Blair and William Duff. These authors argued that modern society communicates with a commercial and rational language unfavourable to natural or passionate expression. Social progress, though desirable, has thus brought conditions that are particularly adverse for the appearance of original poetic genius. ${ }^{32}$ Blair, for example, takes Blackwell's analysis of ancient 'manners' as the model for understanding Ossian's comparative genius:

The manners of Ossian's age [...] were abundantly favourable to a poetical genius. The two dispiriting vices, to which Longinus imputes the decline of poetry, covetousness and effeminacy, were as yet unknown. They lived a roving indolent life; hunting and war their principal employments; and their chief amusements, the musick of bards and 'the feast of shells'.$^{33}$

Although Blair states that he takes his primitivist cue from Longinus, the framework is conspicuously characteristic of Scottish Enlightenment historiography and ultimately dependent on terms derived from Thomas Blackwell. Ossian is shaped by the manners of his age in much the same way as Blackwell's Homer. Blackwell's argument that there is a 
JOBNAME: No Job Name PAGE: 6 SESS: 26 OUTPUT: Mon Sep 3 17:53:35 2012

/v2451/blackwell/journals/jecs_v0_i0/jecs_531

6

RONNIE YOUNG

'Progression of Manners' in human affairs which enables the critic to take the manners depicted in ancient literature as an index of progress and thereby situate the poet in a specific stage of history. For Blackwell, Homer's genius was the product of transition between the first two of three stages of Greek history; for Blair, Ossian's genius is the product of the first stage of a four-stage theory of history refined by later Enlightenment intellectuals such as Adam Smith. ${ }^{34}$ It is within a 'hunter' culture, the first stage in human societal development prior to 'pasturage', 'agriculture' and finally 'commerce', that Ossian's poetry is composed and indeed in which poetic genius can appear at its full pitch. ${ }^{35}$ Besides providing a strong martial tradition from which poetry can draw subject matter, such a period is characterised by naturalistic expression in a tendentiously metaphoric language of imagination. On a comparative historical basis, the same stage of society produced Homer ('For though Homer lived more than a thousand years before Ossian', writes Blair, 'it is not from the age of the world, but from the state of society, that we are to judge of resembling times'), ${ }^{36}$ the touchstone against which Ossian is measured:

In such times as these, in a country where poetry had been so long cultivated, and so highly honoured, is it any wonder that among the race and succession of bards, one Homer should arise; a man who, endowed with a natural happy genius, favoured by peculiar advantages of birth and condition, and meeting in the course of his life, with a variety of incidents proper to fire his imagination, and to touch his heart, should attain a degree of eminence in poetry, worthy to draw the admiration of more refined ages? ${ }^{37}$

Again, Blair's stress on the crucial role played by environment in the development of ancient genius can be viewed as Blackwellian through and through.

Beattie, for his part, is not interested in tracing the progress of ancient genius, and the progress of Edwin's genius is, as Pittock argues, less concerned with situating the bard in a specific historical context than with tracing his developing imagination. ${ }^{38}$ Yet we can still detect Blackwell's influence in the role that environment plays in shaping that imagination. As Conrad Brunström has suggested, Blackwell's Homer provides a model for Edwin as solitary bard:

One of Beattie's earliest encouragers was Thomas Blackwell, the Aberdonian professor whose Inquiry into the Life and Writings of Homer (I735) is a speculative survey of the conditions personal, historical, social and geographical - required to produce an epic poet. Blackwell's bard is a loner, materially poor and prone to introspection. Imaginative endeavour comes easier to those whose isolation precludes distractions: 'When alone, we are obliged to furnish out our own Entertainment; we must recollect ourselves and look within, if there be anything that merits our Attention'. The Minstrel similarly celebrates solitude as the true basis for creative sublimity. ${ }^{39}$

Besides an incipient Romantic solitude, the 'speculative survey' of conditions that Blackwell took to produce Homer's genius can be taken as a further model for Beattie's poem. Edwin's bucolic upbringing as son of a 'shepherd swain', and his own inclinations towards minstrelsy are the 'personal' conditions explored in stanzas II-22. From his earliest age Edwin shows a leaning towards poetry and music:

And yet poor Edwin was no vulgar boy;

Deep thought oft seem'd to fix his infant eye.

Dainties he heeded not, nor gaude, nor toy,

Save one short pipe of rudest minstrelsy. (I.I8) 
Edwin is thus first introduced in terms that underline his natural genius: as a person, Edwin is reflective and introverted yet drawn to music. Yet such natural leanings are crucially nurtured by the 'age' and environment in which Edwin lives. The 'historical' conditions of Beattie's poetic survey of genius are first established in the I77I Advertisement to the poem:

My design was, to trace the progress of a Poetical Genius, born in a rude and illiterate age, from the first dawnings of fancy and reason, till that period at which he may be supposed capable of supporting the character of A MINSTREL, that is, of an itinerant poet and musician. (p.v)

This approach has its roots in Blackwell's historical outlook, suggesting more a stage in human progress than an identifiable historical period. Even the vague reference to "Gothic days' in Book I does not alter the initial invitation to understand the setting within a comparative historical framework of manners and literacy rather than a definite time period..$^{40}$ In terms of Edwin's development, the key factor here is that he is not born in the present age, which is presented as morally compromised and corrupted by ambition, luxury and scepticism. If Edwin is displaced from present-day society by being born in a less progressed age, he is nevertheless exposed to the right kind of manners. For 'social' conditions, Edwin may at first appear to shun society, as in his famous solitary wanderings (see I.I9-34) yet the fact remains that Edwin is exposed to the pastoral manners of his parents and the folk tradition transmitted through the beldam of Book I. For 'geographical' conditions, stanzas 2I-4 of Book I are devoted to description of a natural world that appears favourably remote, beautiful and sublime:

\author{
And oft the craggy cliff he loved to climb, \\ When all in mist the world below was lost. \\ What dreadful pleasure! there to stand sublime, \\ Like shipwreck'd mariner on desert coast, \\ And view th' enormous waste of vapour, tost \\ In billows, lengthening to th' horizon round, \\ Now scoop'd in gulfs, with mountains now emboss'd! \\ And hear the voice of mirth and song rebound, \\ Flocks, herds, and waterfalls, along the hoar profound! (I.23)
}

This acts as a suitable environment for the developing genius. Edwin may be born into the Scots pastoral background of his 'shepherd-swain' father and a sentimental domesticity that prefigures Robert Burns' 'Cottar's Saturday Night', but just as important for the development of his poetic self is the placement of Edwin at the edge of a wild nature into which he can escape, experience the beautiful and sublime aspects of that nature, and indulge in his own sensibility and Romantic solitude. Much of Book I, in other words, can be read not only as the semi-autobiographical study of a gifted but isolated poet but as the conjectural representation of conditions which make the development of Edwin's genius appear credible.

In addition to Blackwell's analysis of genius as it relates to environment, Marischal produced other approaches that would help shape Beattie's poem. In I745 Blackwell's colleague David Fordyce published an important set of Dialogues Concerning Education, in which there appeared significant reflections on genius in relation to education. Fordyce had taught Alexander Gerard in the early $1740{ }^{4 \mathrm{I}}$ and it was as successor to Fordyce 
JOBNAME: No Job Name PAGE: 8 SESS: 26 OUTPUT: Mon Sep 3 17:53:35 2012

/v2451/blackwell/journals/jecs_v0_i0/jecs_531

(following his death at sea in I75I) that Gerard taught Beattie. Like much of the surrounding intellectual activity at Marischal, which laboured under the regent system until I753, Fordyce's Dialogues were concerned with educational reform. It is in this context that there appears a dialogue about the relative merits of 'Education and Non-education' in the encouragement of natural genius. In Dialogue VI, Fordyce has his pertinently named character Eugenio advocate a wide-ranging 'natural' system of education in order to produce 'more original Genius's than we normally meet with'. ${ }^{42}$ Eugenio here takes the Longinian view that genius may be hampered by too great exposure to critical rules:

Thus had Homer's Genius been formed and chastised by the rigid Rules of Art, his Imagination would never have run with such a swift and unbounded Career, through every Region of Nature; had he lived in more polished Times, and undergone the Discipline of Schools and Colleges, and there been instituted in the Rules of Criticism, and the whole Mechanism of Poetry, as it has been opened in modern Times; I dare say he would never have attained that Perfection of Poetry, or painted Men and Manners with that Truth, and expressive Variety, for which he has he has been so justly celebrated in all Ages. ${ }^{43}$

There ensues a lengthy debate, in which various opinions are voiced, from the character Constant's view that early education is necessary to induce true principles and good manners $\lambda_{\text {to }}$ Sophron's expedient that the pupil should be acquainted with human history to ensure that education remain liberal and wide-ranging enough. In his summation, the character Philander attempts to synthesise viewpoints by advocating history as 'a Study of the first Rank, and most general Use', as it gives valuable knowledge of mankind, human progress, the growth of liberty, the 'Dangers of Arbitrary Power' and so on. ${ }^{44}$

There was some debate in the period, then, as to the part education should play in nurturing genius, from the view that too much exposure to the rules of art deadens original genius to the belief that without liberal education fancy remains misdirected. Book II of The Minstrel engages with such debates. The Hermit, for example, echoes Fordyce's concerns about the necessity of instruction for the young explorer:

soft and smooth are fancy's flowery ways.

And yet even there, if left without a guide,

The young adventurer unsafely plays. (II.39) ${ }^{45}$

In Fordyce's Dialogues the character Philander had argued that

the boldest youthful Traveller, who ever set out in the Road of Science, though furnished with the choicest Gifts of nature, and prompted by the keenest Curiosity, will need a guide to lead him part of the way, and point out to him the principal Quarters, the high Roads and Boundaries of Knowledge, that he may not distress himself to little purpose amidst the thorny Brakes, nor lose his way in the uncultivated Wilds. ${ }^{46}$

The Hermit's words thus suggest that Beattie shared similar concerns about the dangers of 'untutored' genius to his Marischal mentors. This advocacy of education is supported by the fact that Beattie ultimately traces the progress of genius over the course of two books, a course in which Book II becomes as integral to Edwin's training as minstrel as the solitary unchecked wanderings of Book I which provided such a model for Wordsworth and other Romantics. Specifically, the Hermit of Book II prepares Edwin for a world in which he must later ply his trade. In line with the reformist views of Beattie's colleagues at Marischal, then, education is to be practical and to prepare the youth for active offices in the real world. ${ }^{47}$ 
JOBNAME: No Job Name PAGE: 9 SESS: 26 OUTPUT: Mon Sep 3 17:53:35 2012

/v2451/blackwell/journals/jecs_v0_i0/jecs_531

James Beattie and the Progress of Genius in the Aberdeen Enlightenment

On the most basic level, we could see Books I and II representing the different stages in the education of genius, where Book I allows the young Edwin to range wildly among nature and Book II reins him in. Book I after all proclaims 'Perish the lore that deadens young desire!' and allows Edwin to 'Indulge gay Hope, and Fancy's pleasing fire' (I.33). Book II, on the other hand, foregrounds the change from Edwin's childhood to adolescence and undertakes to 'smite the Gothick lyre with harsher hand' (II.3) and ready Edwin for the wider world:

\author{
'Perish the lore that deadens young desire' \\ Is the soft tenor of my song no more. \\ Edwin, though loved of heaven, must not aspire \\ To bliss, which mortals never knew before. \\ On trembling wings let youthful fancy soar, \\ Nor always haunt the sunny realms of joy; \\ But now and then the shades of life explore; \\ Though many a sound and sight of woe annoy, \\ And many a qualm of care his rising hopes destroy. (II.4)
}

It is to the old Hermit encountered by Edwin in the woods that the minstrel's mature education is entrusted. The Hermit begins by teaching history, and Edwin is persuaded by the old sage of the value of civil history, particularly in promoting the values of liberty and progress (II.33). After history comes philosophy. First, Edwin is taught logic which 'learns, from facts compared, the laws to trace, / Whose long progression leads to Deity' (II.46). The hermit then proceeds to moral philosophy, which acts to 'regulate man's moral frame' by easing 'cares' and 'discord' and promoting 'harmony' (II.52). Finally, Edwin is taught the principles of political philosophy and that it is the philosopher

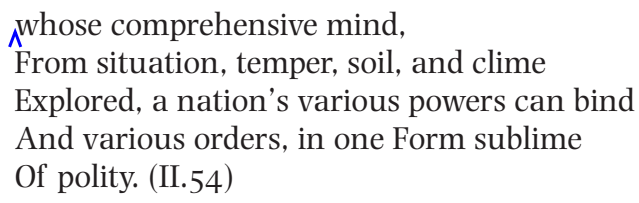

The set of subjects taught by the Hermit - history, logic, moral philosophy, politics - is particularly significant. The Arts degree at Marischal had been overhauled in the early I750s by staff including principal Blackwell and Gerard, who was tasked with publishing this new Plan of Education in $1755 .^{48}$ Their reforms instituted a practical system of studies that would prepare students more effectively for the modern world and be "more useful for the various purposes of human life'. Instead of beginning with Logic, as under the traditional scholastic curriculum, the new course started with 'Elements of History, Natural and Civil' and proceeded through Natural Philosophy to 'Morals, Politics, Logic and Metaphysics' in the student's final year. ${ }^{49}$ Logic, Gerard argued, is to be a later 'review' of the methods one has employed after reason has been allowed to 'spontaneously exert itself' in the sciences, and will eventually offer 'the security of reflection, against employing wrong methods of proof and improper kinds of evidence, additional to that of instinct and natural genius'.$^{50}$ In The Minstrel Edwin experiences the same order of education: his instinct and genius at first roam free, but he eventually progresses from History to Philosophy and by that means gains experience of the world. In this respect Edwin is more or less subjected to the reformed Arts curriculum at Aberdeen. 
JOBNAME: No Job Name PAGE: 10 SESS: 26 OUTPUT: Mon Sep 3 17:53:35 2012

/v2451/blackwell/journals/jecs_v0_i0/jecs_531

IO

RONNIE YOUNG

II.

In I76I Beattie joined the Aberdeen Philosophical Society on the nomination of Gerard. Beattie's election to the 'Wise Club' meant that the two would be active together in the contemplation of genius in the company of an august and select society that included Thomas Reid, George Campbell, John Gregory and James Dunbar. The society met fortnightly between I758 and I773. As the questions recorded in the society's minute book show, discussion ranged across the whole spectrum of Enlightenment thought, and within this it is significant to note that 'literary' and aesthetic questions feature regularly alongside philosophical and scientific problems. Such meetings provided a platform for drafts of the major publications of Aberdeen's Enlightenment, which included Thomas Reid's Inquiry into the Human Mind, On the Principles of Common Sense (I 764), John Gregory's Comparative View of the State and Faculties of Man (I765), Alexander Gerard's Essay on Genius (I774), George Campbell's Philosophy of Rhetoric (I776) and James Dunbar's Essay on the History of Mankind in Rude and Cultivated Ages (I780)..$^{\text {I }}$ With regards to Beattie, the Wise Club has been acknowledged as instrumental in getting the author's thoughts on philosophy and criticism into print in such works as his Essay on the Nature and Immutability of Truth, in Opposition to Sophistry and Scepticism (I77O), ${ }^{52}$ but we can also consider the role of discussions about genius in influencing Beattie's poetic production. ${ }^{53}$

Out of the I26 questions proposed by members of the Philosophical Society, four of the proposed were devoted to the subject of genius, two of which were eventually discussed. This may not seem like a lot, but it is actually significant when one considers the range of subjects discussed by the society - natural philosophy and history, moral philosophy and political economy, aesthetics, rhetoric and belles-lettres, and more - and that questions on genius feature more often than other topical critical questions such as taste, which was discussed only once. ${ }^{54}$ Moreover, this activity was complemented by numerous discourses delivered by Gerard. From the questions proposed we gain some insight into the society's approach to the subject. Regarding the two questions actually discussed, both show the lingering influence of Blackwell. Question 75, 'Whether there is any degeneracy of genius in the moderns', was proposed by Thomas Gordon and discussed on 26 March I 765, while Beattie and Gerard were present. The equally Blackwellian question 'Whether any account can be given of the causes, why great Geniuses have arisen at the periods which have been most remarkable for them, and why they have frequently arisen in clusters?' was proposed by Gerard and discussed without Beattie on I2 December I769. Of the questions that never made the grade, Beattie himself proposed question 78 , on 'Whether Music, Painting or Poetry gives the greatest scope to Genius'. Despite the fact that this question was later withdrawn and replaced by the perhaps more typically Aberdonian question 'What is the difference between Common Sense and Reason', Beattie's initial proposal suggests that the subject of genius was on his mind before he began writing The Minstrel. Ulman suggests that Beattie's second and third discourses to the society were revised to become the 'Essay on Poetry and Music, as they affect the Mind' published with the 1776 edition of his Essay on Truth, and, given the title of the question initially proposed by Beattie in December I765, it is possible that the projected discourse on genius was intended to be part of the same series. ${ }^{55}$

An earlier question, 'In the Perfection of what Faculty does Genius consist? Or if in a Combination of Faculties, What are they?' was proposed at the start of the society's life by John Farquhuar in I758, before Beattie became a member, but was, as the society's minutes record 'Superceded because the subject of Mr Gerards Discourses'. ${ }^{56}$ Even in being removed, this question points to the bulk of activity related to genius in the society's 
JOBNAME: No Job Name PAGE: 11 SESS: 26 OUTPUT: Mon Sep 3 17:53:35 2012

/v2451/blackwell/journals/jecs_v0_i0/jecs_531

James Beattie and the Progress of Genius in the Aberdeen Enlightenment

proceedings: that is, as a platform for a series of discourses by Gerard that culminated in the publication of his Essay on Genius in $1774 .{ }^{57}$ Gerard read at least eighteen discourses on genius over the course of the society's existence, ${ }^{58}$ the basic content of which appears to have been preserved when eventually published as his Essay on Genius. The Essay was not, of course, published until the same year as Book II of The Minstrel, but Beattie had earlier exposure to its contents through the Philosophical Society and according to their minutes attended at least fourteen of Gerard's discourses.

Gerard's discourses ranged from 'the Nature and Variety's of genius' through 'the effect of the passions on the association of our ideas' to 'the kinds of genius' - that is, the poetic and the philosophical (a topic that Beattie himself discussed in correspondence). ${ }^{59}$ They show that the Blackwellian account of poetic genius, which laid emphasis on environmental causes and stadial history, was being complemented by a new analytical approach to the subject which laid emphasis on the psychology of genius. Gerard was one of the pioneers of the psychological approach and saw his analysis as part of a wider "science of human nature', ${ }^{60}$ all of which chimes with the philosophy of fellow society members Reid, Gregory, Campbell and Beattie himself. Rather than producing a conjectural history about how genius was better in the good old days, then, Gerard discoursed on the faculties of the mind that form genius and the psychological principles that cause it to vary from individual to individual.

That is not to say that the two approaches to genius were exclusive. In I767 the Marischal-educated William Duff beat Gerard to print with his Essay on Original Genius, which also takes a psychological approach yet retains much of the primitivist outlook of Blackwell and Blair. As in other areas of Scottish Enlightenment thought, the study of human nature and of social progress is part of the same enquiry. Accordingly, Duff sets out by analysing Genius into its essential psychological components of imagination counterbalanced by judgement, and it is only in the closing section of his essay that he proposes that it is early periods of society that allow the most scope for the kind of imaginative expression indicative of original poetic genius. ${ }^{6 \text { I }}$ Fiona Stafford has pointed to a conflict between Blackwell and Gerard's idea of genius, particularly as Blackwell emphasises 'spontaneity' and 'emotional expression' while Gerard emphasises 'refinement' of taste and 'utilitarianism'. That these conflicting influences are ultimately said to 'come pouring out' in Macpherson's writing suggests that they were in no way disabling for the creative writer. ${ }^{62}$ Indeed, we can also see Beattie's Minstrel as a place in which such influences converge productively - that is, as a poetic mediation between the spontaneity and expressivity of bardic genius and the utilitarian outlook of Gerard that Beattie would follow in his later writing.

Key here is Gerard's emphasis on taste and judgement. Earlier I discussed the idea that education is crucial to the development of Edwin's genius; by way of explanation we can now add that education is crucial because it teaches Edwin these very qualities:

Of late, with cumbersome though pompous show

Edwin would oft his flowery rhyme deface,

Through ardour to adorn; but Nature now

To his experienced eye a modest grace

Presents, where Ornament the second place

Holds, to intrinsick worth and just design

Subservient still. Simplicity apace

Tempers his rage: he owns her charm divine,

And clears th'ambiguous phrase, and lops th'unwieldy line. (II.58) 
JOBNAME: No Job Name PAGE: 12 SESS: 26 OUTPUT: Mon Sep 3 17:53:35 2012

/v2451/blackwell/journals/jecs_v0_i0/jecs_531

\section{I2 RONNIE YOUNG}

Side-stepping the irony of the final line and Beattie's own inability to lop the unwieldy hexameter that has been forced on him by his choice of Spenserian form, this stanza shows the positive effect education has had in refining Edwin's poetic composition. For Joan Pittock these lines are 'pre-Wordsworthian' in that 'nature inculcates the proper use of rhetoric' and Edwin's experience suggests to him a 'purity of style free from the trappings of conventional rhetorical ornament' ${ }^{63}$ Wordsworthian or not, the metaphor of cultivation here suggests that Edwin is able to improve on nature by means of the judgement he has gained through learning - and this sits nicely with Gerard's views on taste and genius and Beattie's own later critical writing, both of which emphasise the need to refine what nature provides. Beattie had in all probability heard Gerard's argument about taste - later published in part III of Gerard's Essay as ‘Taste essential to genius for the Arts' - some time after I769 and before I773, when the final stanzas of The Minstrel were composed. ${ }^{64}$ To Gerard taste is a kind of judgement and therefore regulates the imagination by "perceiving what is faulty, rejecting what is redundant, marking what is incomplete, correcting and perfecting the whole'. ${ }^{65}$ That Edwin's education has taught him this kind of judgement shows Beattie adopting a mainstay of Aberdeen thought. Gerard, like Duff, saw judgement as a fundamental component of genius, working alongside imagination to regulate the power of invention. ${ }^{66}$ In Gerard's terms,

a fine imagination left to itself, will break out into bold sallies and wild extravagance, and overstep the bounds of truth or probability: but when it is put under the management of sound judgment, it leads to solid and useful invention, without having its natural sprightliness in the least impaired. ${ }^{67}$

Book II of The Minstrel offers a structural rehearsal of such views, showing that Edwin's imagination is not left to itself: ultimately, any wild extravagance displayed by Edwin - the 'ambiguous phrase', the 'unwieldy line' - is 'cleared' and 'lopped' by an individual who is now able to show tasteful restraint. If Book II reins Edwin's imagination in, then, it does so as a matter of necessity and in a manner consistent with the thoughts of Beattie's contemporaries on the refinement of genius.

Beattie's own later 'Remarks on Genius', published in his Dissertations Moral and Critical (I 783), show a similar reliance on Gerard. There Beattie acknowledges Gerard's influence when he proposes not to minutely analyse 'Taste and Genius' as

That matter has been fully and accurately discussed by an abler hand; I mean, by the learned Dr Gerard: to whose writings and conversation, (for he was my master in philosophy) and to whose friendship on many occasions in life, I am happy in this opportunity of declaring, that I am deeply indebted. ${ }^{68}$

In particular, Beattie follows his old master's definition of genius as 'the faculty of invention; by means of which a man is qualified for making new discoveries in science, or for producing original works of art' ${ }^{69}$ In his Dissertations Beattie says, 'The talent of invention, applied to useful purposes, is called Genius', a definition he later repeats in his Elements of Moral Science (I790-93), suggesting that this material was taught by Beattie at Aberdeen..$^{\circ}$ Beattie then goes on to add that 'to qualify the human mind for invention [...] good sense, as well as imagination, are necessary', a provision also derived from Gerard's view on the necessity of judgment as outlined above. Specifically, Beattie stresses how judgement, or 'good sense' as he alternatively terms it, performs the same function outlined by Gerard and echoed in Book II of The Minstrel - that is, of complementing and 
JOBNAME: No Job Name PAGE: 13 SESS: 26 OUTPUT: Mon Sep 3 17:53:35 2012

/v2451/blackwell/journals/jecs_v0_i0/jecs_531

James Beattie and the Progress of Genius in the Aberdeen Enlightenment

directing the imagination. It is this regulatory power that distinguishes genius from a merely lively or disorderly imagination:

To qualify the human mind for invention, that is, for forming new and useful arrangements, of things or of ideas, experience, and good sense, as well as imagination, are necessary. In dreams, and in disease, imagination often operates with astonishing vivacity: but that is not Genius, because it is not regulated by knowledge or judgement, and tends to no useful purpose..$^{7 \mathrm{I}}$

Beattie employs this qualified view of the powers of imagination to deliberately challenge what he sees as a widespread and long-standing critical misconception about the selfsufficient nature of poetical genius:

I mention this, with a view to combat an opinion, as old at least as the age of Horace, and not uncommon in modern times; - that Genius, especially poetical genius, is nothing more than a certain warmth of fancy, or enthusiasm of mind, which is all-sufficient in itself, and stands in no need of judgement, or good sense, to give it direction and regularity. Under the influence of this idle conceit, Horace tells us, that some of the poets of his time shut themselves up in cells, avoiding the scenes of observation and business, and when they shewed themselves in publick, affected a total disregard to the customs of the world: as if ignorance, rusticity, and madness could qualify them for instructing or entertaining mankind. But Horace teaches a different doctrine. He declares Good Sense to be the source of all good writing: and recommends it to the man of genius, to study nature, to mingle in society, and to make himself acquainted with the manners and characters of men, and with the various ways in which they express their passions and sentiments. ${ }^{72}$

As in Gerard, then, judgement is here given the task of regulating poetic imagination, but Beattie goes further in outlining 'Good Sense' as Horace's recommendation for 'the man of genius' to mingle in society and observe human nature directly. Judgement entails not only imaginative self-regulation but also direct social engagement.

Where Beattie's thinking seems to have evolved by this stage is in his emphasis on useful purpose and his utilitarian views of genius. Here Beattie re-imagines the poetic genius as a socially active rather than solitary Romantic figure:

Arts and sciences owe their improvement, and genius its most illustrious displays, not to monks, and hermits, and half-witted enthusiasts, but to such men as Homer, Socrates, Xenophon, Sophocles, Demosthenes, Cicero, Cesar, Bacon, Shakespeare, Milton, Clarendon, Addison, Lyttleton: men, who studied life and manners, as well as books; who took part in the business of society; and gave proof of the soundest judgment, as well as of a most comprehensive mind. ${ }^{73}$

What we do not see in The Minstrel, which ends before Edwin goes out into the world, but what instead appears in Beattie's later critical writing is a view of poetic genius that fits alongside other capacities within a utilitarian vision of society. It is difficult to imagine what would be a suitably useful role for Edwin were there to be a third book of The Minstrel, although one early letter by Beattie did suggest that Edwin's future utility might involve resisting invading Danes. ${ }^{74}$ Such a suggestion hints at an underlying civic humanist outlook as it stresses an active, patriotic role for the poet. In fact, one sees a further hint towards Edwin's socially active future in one of the more subtle of Beattie's revisions to the I784 edition of the poem. Whereas Beattie's stated design in the original preface to Book 
JOBNAME: No Job Name PAGE: 14 SESS: 26 OUTPUT: Mon Sep 3 17:53:35 2012

/v2451/blackwell/journals/jecs_v0_i0/jecs_531

\section{I4 RONNIE YOUNG}

I of I77I was to trace the progress of a poetical genius 'till that period at which he may be supposed capable of supporting the character of A MINSTREL' (p.v), by I784 the design has altered to instead follow Edwin 'till that period at which he may supposed capable of appearing in the world as A MINSTREL'. ${ }^{75}$ This is a small revision, but one that places less emphasis on the development of individual character and gestures more towards Edwin's future entrance into society.

We cannot ascertain what Beattie intended by altering the Preface in this manner, but the I784 alteration is consistent with the line of thought that Beattie was pursuing in his critical writing around this time, in which Beattie emphasises that genius has a firm place in society. In the Dissertations those pillars of poetic genius Homer, Shakespeare and Milton were not 'hermits': they 'took part' in society; social disengagement, by contrast, is associated with 'ignorance', 'madness' or the psychological disorder of 'half-witted enthusiasts'. The wider implications of this position are that moral, utilitarian and civic humanist dimensions shape Scottish thought on genius and consequently that any easy association of poetic genius with proto-Romantic solitude must be qualified. This envisaged social role for the poetic genius does not involve re-instating the communal role of the bard, and does not therefore overturn Pittock's assertion that Beattie domesticates the bard figure by divesting him of community function; ${ }^{76}$ rather, Beattie's later critical writing examines the social role of genius within a wider, geographically non-specific civic sphere. In this writing Beattie asserts that genius may be uncommonly endowed but that rarity is according to the will of God, who has intended that in civil society 'there must be some to contrive and command, but that the far greater have nothing to do but obey'. He continues:

If every man were an inventor and a projector, there would be such a multiplicity of rivalships
and jarring interests, and such a spirit would predominate of independence and of pride, as
could not fail to introduce confusion into human affairs; and many of the lower employments
of life, which are essential to the general welfare, would be totally abandoned. For if all men
were equal in abilities, they would aspire to an equality of condition; a state of things, which
is proved by the experience of every age to be unattainable; and of which, if we consider how
necessary subordination is to publick good, we shall be satisfied, that, if it could be attained,
it would not be expedient. As Providence has made us differ in the form of our bodies; and
some are swift, and others unwieldy, some weak, and others strong; it would seem to be no less
the intention of Providence, that we should differ in the capacity of our minds: for thus we are
better qualified to discharge, with pleasure to ourselves, and with benefit to the publick, the
duties belonging to the different professions that take place in society.7

Subordination is written into human nature and promotes the smooth functioning of society, a structure in which even the extraordinary abilities of original genius have their place.

This view of the providential 'functionalism' of human genius was shared by many of Scotland's moderates, but it was not without opponents. Years earlier, the English curate William Sharpe had rejected such a view in his Dissertation of Genius of I755. Drawing on the Lockean idea of the mind as tabula rasa as evidence of an original equality among men, Sharpe says on the issue of whether 'the differences of Genius are necessary in order to form a subordination in society' that 'the unequal opportunities of cultivation [...] will answer the purpose in every point of view as well, as by supposing the distinction to be essentially copy'd from the plan and form of nature' ${ }^{78}$ But the radical individualism represented by the Lockean tradition stands in contrast to the civic humanism of Aberdeen's 'common sense' tradition, which tends to stress man as an innately social animal 
JOBNAME: No Job Name PAGE: 15 SESS: 26 OUTPUT: Mon Sep 3 17:53:35 2012

/v2451/blackwell/journals/jecs_v0_i0/jecs_531

James Beattie and the Progress of Genius in the Aberdeen Enlightenment

and innate distinctions which, in the analysis of genius, are held to bolster social organisation. This latter approach was an aspect of William Duf's study of genius in I767, in which Duff began by noting

the unequal distribution of natural talents among mankind; that as there is a great diversity of these observable among them, so the same talents are possessed in very different proportions by different persons. This variety both in the kind and degree of mental accomplishments, while it indicates that man was formed for society, doth likewise clearly point out the respective stations in life which every individual is best calculated to fill and adorn. ${ }^{79}$

Duf's thoughts were published the same year as Adam Ferguson's pioneering work in sociology, An Essay on the History of Civil Society, a notable context for the view that men are, as Ferguson put it, 'fitted for different stations in life': far from being born equal and 'prior to any political institution whatever, men are qualified by a great diversity of talents', says Ferguson, 'to act a variety of parts' - a succinct formulation of Scots claims for social subordination being hard-coded into human nature. ${ }^{80}$

It is not only Gerard, then, but also the Aberdeen-educated Duff who shapes Beattie's later critical writing, particularly in informing Beattie's civic humanist outlook on the utilitarianism of human genius in general. Such views have a knock-on effect when it comes to original poetic genius in particular. They explain why Blackwell's unruly and wild bard has been transformed in Beattie's later critical writing into a much more refined Homer 'who studied life and manners, as well as books' and 'who took part in the business of society'. ${ }^{8 \mathrm{I}}$ Ultimately we are left with a vision of the poetic genius not as one who stands apart from society a 'wayward wight' or who observes that society at a Wordsworthian remove, but as an inventor who plays an active and useful role within civil society. As a 'hot-bed of genius', then, Aberdeen produced a vision of poetic genius as much attuned to the civic humanism of the Scottish Enlightenment as to Romantic individualism.

\section{NOTES}

I. See W. Riddick, 'Beattie's Minstrel and the Lessons of Solitude', in Jennifer J. Carter and Joan Pittock (eds), Aberdeen and the Enlightenment (Aberdeen: Aberdeen University Press, I987), p.325-30; Joan H. Pittock, 'James Beattie: A Friend to All', in David Hewitt and Michael Spiller (eds), Literature of the North (Aberdeen: Aberdeen University Press, I983), p.56; Everard H. King, 'James Beattie and the Growth of Romantic Melancholy', Scottish Literary Journal 5 (I978), p.24-5; Everard H. King, James Beattie's 'The Minstrel' and the Origins of Romantic Autobiography (Lewiston and Lampeter: E. Mellen Press, I992). Roger Robinson, 'The Origins and Composition of James Beattie's Minstrel', Romanticism 4 (I998), p.224-40.

2. Dafydd Moore, 'The Ossianic Revival, James Beattie and Primitivism', in The Edinburgh History of Scottish Literature, vol. II, Enlightenment, Britain and Empire, ed. Susan Manning and others (Edinburgh: Edinburgh University Press, 2007), p.98.

3. See, for example, L. Davis, I. Duncan and J. Sorenson (eds), Scotland and the Borders of Romanticism (Cambridge: Cambridge University Press, 2004).

4. Murray Pittock, Scottish and Irish Romanticism (Oxford: Oxford University Press, 2008), p.I34-6.

5. Rhona Brown, 'The Long Lost James Beattie: The Rediscovery of The Grotesquiad' (forthcoming). I am grateful to Dr Brown for allowing me to read a draft of her article.

6. Ronnie Young, 'Genius, Men and Manners: Burns and Eighteenth-Century Scottish Criticism', Scottish Studies Review 9 (2008), p.I29-47.

7. Quoted in Robinson, 'Origins and Composition', p.234.

8. Beattie, The Minstrel; or, The Progress of Genius. A Poem (London: E. \& C. Dilly, and Edinburgh: A. Kincaid \& J. Bell, I77I), p.v. Unless otherwise indicated, subsequent references to the first book of The Minstrel will be to this edition and, for lines of verse, will take the form of book and stanza numbers.

9. For a discussion of Percy's re-invention of the minstrel figure see Kathryn Sutherland 'The Native Poet: The Influence of Percy's Minstrel from Beattie to Wordsworth', Review of English Studies 33 (I982), p.4I7-8.

Io. Laura Bandiera, " "In Days of Yore How Fortunately Fared the Minstrel”: Towards a Cultural Genealogy of Wordworth's Preface to Lyrical Ballads', European Journal of English Studies 6 (2002), p.I93. 
JOBNAME: No Job Name PAGE: 16 SESS: 26 OUTPUT: Mon Sep 3 17:53:35 2012

/v2451/blackwell/journals/jecs_v0_i0/jecs_531

\section{I6 RONNIE YOUNG}

II. In a footnote to Book I, Beattie alludes to Percy as justification for his choice of Scotland as the location for this poem: that is the 'North Countrie' from which Percy said most minstrels emerged (p.6). Cf. Thomas Percy, Reliques of Ancient English Poetry (London: J. Dodsley, I765), p.xxi-xxii.

I2. A recent discussion of Percy's response to Macpherson appears in Robert Rix, 'Thomas Percy's Antiquarian Alternative to Ossian', Journal of Folklore Research 46 (2009), p.I97-229.

I3. Philip Connell, 'British Identities and the Politics of Ancient Poetry in Later Eighteenth-Century England', Historical Journal 49 (2006), p.I67-76.

I4. Percy, Reliques, p.xv.

I5. Percy, Reliques, p.vi.

I6. James Macpherson, Fragments of Ancient Poetry, Collected in the Highlands of Scotland (Edinburgh:

G. Hamilton and J. Balfour, I760), p.vii.

I7. Hugh Blair, A Critical Dissertation on the Poems of Ossian (London: T. Beckett \& P. A. De Hondt, I763), p.I5.

I8. See Beattie's letter of 29 March I 762 to Robert Arbuthnott reprinted in William Forbes, An Account of the

Life and Writings of James Beattie, 2 vols (Edinburgh: Constable, Creech et al., I806), vol. I.57-6o.

I9. See Moore, 'The Ossianic Revival', p.93-4, 96-7.

20. Moore, 'The Ossianic Revival', p.90.

2I. Fiona Stafford, The Sublime Savage: A Study of James Macpherson and the Poems of Ossian (Edinburgh: Edinburgh University Press, I988), p.37.

22. Mary Catherine Moran, 'Duff, William', in Oxford Dictionary of National Biography, online, http:// www.oxforddnb.com/view/article/8I74 (accessed 8 August 20II).

23. Forbes, An Account, p.30.

24. For a discussion of Blackwell's influence on Macpherson at Aberdeen see Stafford, Sublime Savage, p.2834. Cf. John Dwyer, 'The Melancholy Savage: Text and Context in the Poems of Ossian', in Howard Gaskill (ed.), Ossian Revisited (Edinburgh: Edinburgh University Press, I99I), p.I75.

25. Margaret Forbes, Beattie and his Friends [1903] (Altrincham: J. Martin Stafford, I990), p.5.

26. Joan Pittock, 'James Beattie: A Friend to All', p.55.

27. Thomas Blackwell, An Enquiry into the Life and Writings of Homer (London:, I735), p.4.

28. Blackwell, An Enquiry, p.5.

29. See Blackwell, An Enquiry, pp.II-I2.

30. Blackwell, An Enquiry, p.46.

3I. Blackwell, An Enquiry, p.26.

32. See, for example, Blair, A Critical Dissertation, p.2-4; William Duff, An Essay on Original Genius; and Its Various Modes of Exertion in Philosophy and the Fine Arts, Particularly in Poetry (London: Edward and Charles Dilly, I767), p.vii. See also Moore, 'The Ossianic Revival', p.92-3, and Young, 'Genius, Men and Manners', p.I38-9. For Blackwell's influence on Blair, see Steve Rizza, 'A Bulky and Foolish Treatise? Hugh Blair's Critical Dissertation Reconsidered', in Ossian Revisited, p.I33-4.

33. Blair, A Critical Dissertation, p.I6.

34. See Adam Smith, 'The Origin and Development of our Property Rights', in Alexander Broadie (ed.), The Scottish Enlightenment: An Anthology (Edinburgh: Canongate Classics, I997), p.478-87.

35. Blair, A Critical Dissertation, p.I6-I7.

36. Blair, A Critical Dissertation, p.22.

37. Blair, A Critical Dissertation, p.I6. See also p.46, for direct comparison of Homer's genius with that of Ossian.

38. Murray Pittock, Scottish and Irish Romanticism, p.I34.

39. Conrad Brunström, 'James Beattie and the Great Outdoors: Common Sense Philosophy and the Pious Imagination', Romanticism 3 (I997), p.25; cf. p.26.

40. Beattie's preface for the revised I784 edition drops the phrase 'illiterate' - perhaps as a result of his research into medieval culture for his essay 'On Fable and Romance' (I783) - but keeps the 'rude age' as setting. See Beattie, The Minstrel, 8th edn (London: Charles Dilly and William Creech, Edinburgh, I784), p.xi.

4I. Joan H. Pittock 'Rhetoric and Belles Lettres in the North East', in Aberdeen and the Enlightenment, p.276-7.

42. David Fordyce, Dialogues Concerning Education (London, I745), p.IIo.

43. Fordyce, Dialogues Concerning Education, p.IIo.

44. Fordyce, Dialogues Concerning Education, p.I36-40.

45. James Beattie, The Minstrel; or, The Progress of Genius. The Second Book (London: Edward \& Charles Dilly; and William Creech, Edinburgh, I774), p.v. All subsequent references to the second book of The Minstrel will be to this edition and will take the form of book and stanza numbers.

46. Fordyce, Dialogues Concerning Education, p.I36.

47. Cf. Stafford, Sublime Savage, pp.26-7.

48. For an overview of the reforms at Marischal, see Paul B. Wood, The Aberdeen Enlightenment: The Arts Curriculum in the Eighteenth Century (Aberdeen: Aberdeen University Press), p.6I-73.

49. Alexander Gerard, A Plan of Education in the Marischal College and University of Aberdeen (Aberdeen: James Chalmers, I755), p.6-7. See also Stafford, Sublime Savage, p.26-7.

50. Gerard, Plan of Education, p.I4.

5I. For an outline of the society's membership and activities see H. Lewis Ulman, The Minutes of the Aberdeen Philosophical Society, I758-I773 (Aberdeen: Aberdeen University Press, I990), p.24-4. 
JOBNAME: No Job Name PAGE: 17 SESS: 26 OUTPUT: Mon Sep 3 17:53:35 2012

/v2451/blackwell/journals/jecs_v0_i0/jecs_531

James Beattie and the Progress of Genius in the Aberdeen Enlightenment

52. Ulman, Minutes, p.37-40; Roger J. Robinson, 'Beattie, James (I735-I803)', Oxford Dictionary of National

Biography online, http://www.oxforddnb.com/view/article/I83I (accessed 8 August 2OII).

53. Cf. Joan Pittock, 'Rhetoric and Belles Lettres in the North East', p.277.

54. See Ulman, Minutes, p.I89.

55. Ulman, Minutes, p.46.

56. Ulman, Minutes, p.I9o.

57. Gerard acknowledges such provenance in his Essay on Genius, noting that it was begun in I 758, when "he was in an office which favoured enquires of this nature' and the same year the Wise Club commenced. Alexander Gerard, An Essay on Genius (London: W. Strahan and T. Cadell, I774), p.iii.

58. The final recorded minutes for the Society read that 'Dr Gerard intimated the [...] to be a continuation of [...]' (Ulman, Minutes, p.I87), suggesting that Gerard planned the subject of his next discourse to be a continuation of his former subject and that he may have read more discourses on genius than are recorded.

59. Ulman, Minutes, p.86, I20, I62. Beattie's letter of I6 November I 766 to Charles Boyd asks 'Do you not think there is a sort of antipathy between philosophical and poetical genius?' and shows his interest in the different 'kinds' of genius. See Letters of James Beattie (London: John Sharpe, I8I9-2I), vol. I.36.

6o. See Gerard, Essay on Genius, p.I-2.

6I. Duff, Essay on Original Genius, p.3-26, 260-96.

62. See Stafford, Sublime Savage p.36.

63. Joan Pittock, 'Rhetoric and Belles Lettres in the North East', p.277.

64. Gerard discoursed on the 'kinds of genius' on I4 November I769 (Ulman, Minutes, p.I6I-2). Since the order of Gerard's discourses is preserved in his Essay on Genius we can conjecture that a discourse dealing with taste, although not explicitly mentioned in the society's minutes, would have followed this discourse, with possible dates being I3 November I770, I2 November I77I or IO November I772. Beattie was present at all these meetings. Robinson suggests that nothing was added to book II of The Minstrel between I770 and I773, which further suggests that stanza LVII was composed some time after February I773 (see Robinson, 'Origins and Composition', p.228-9).

65. Gerard, Essay on Genius, p.393.

66. See Duff, Essay on Original Genius, p.8-Io; Gerard, Essay on Genius, p.7I-95.

67. Gerard, Essay on Genius, p.7I.

68. Beattie, Dissertations Moral and Critical (London: Routledge/Thoemmes Press, I996), p.I46-7.

69. Gerard, Essay on Genius, p.8.

70. Beattie, Dissertations, p.I46. See also Beattie, Elements of Moral Science, 2 vols (London: Routledge/ Thoemmes Press, I996), vol. I.I06; in the section on imagination Beattie writes: 'Now this inventing power is ascribed, as observed already, to the imagination and fancy, and, when regulated by good sense and applied to useful purposes, is called genius.'

7I. Beattie, Dissertations, p.I47.

72. Beattie, Dissertations, p.I47.

73. Beattie, Dissertations, p.I48.

74. See Beattie's letter of November I769 to Thomas Gray in The Correspondence of Thomas Gray, ed. Paget Toynbee and Leonard Whibley, 3 vols (Oxford: Clarendon, I935), vol. III.IO84.

75. Beattie, The Minstrel, 8th edn (p.xi).

76. See Murray Pittock, Scottish and Irish Romanticism, p.I34-6.

77. Beattie, Dissertations, p.I48-9.

78. William Sharpe, A Dissertation upon Genius (London: C. Bathurst, I755; repr. New York: Scholars' Facsimiles and Reprints, I973), p.74-5.

79. Duff, Essay on Original Genius, p.I-2.

80. Adam Ferguson, An Essay on the History of Civil Society (I767), ed. Duncan Forbes (Edinburgh: Edinburgh University Press, I966), vol. I.I0, 63.

8I. Beattie, Dissertations, p.I48.

DR RONNIE YOUNG was educated at Strathclyde University and Sussex University and has taught at Strathclyde, Stirling and the University of Glasgow, where he currently convenes a class on the Scottish Enlightenment. He is series editor for the Scottish Cultural review of Language and Literature (SCROLL) series with Rodopi Press and is also co-editing a volume on the literature of the Enlightenment for the Studies in I8th-Century Scotland series with Bucknell Press. He has published on Robert Burns, Tobias Smollett and Susan Ferrier, and has general research interests in the literary culture of the long eighteenth century and the science of human nature. 
Required software to e-Annotate PDFs: Adobe Acrobat Professional or Adobe Reader (version 8.0 or above). (Note that this document uses screenshots from Adobe Reader $\mathrm{X}$ )

The latest version of Acrobat Reader can be downloaded for free at: http://get.adobe.com/reader/

Once you have Acrobat Reader open on your computer, click on the Comment tab at the right of the toolbar:

닙

This will open up a panel down the right side of the document. The majority of tools you will use for annotating your proof will be in the Annotations section, pictured opposite. We've picked out some of these tools below:

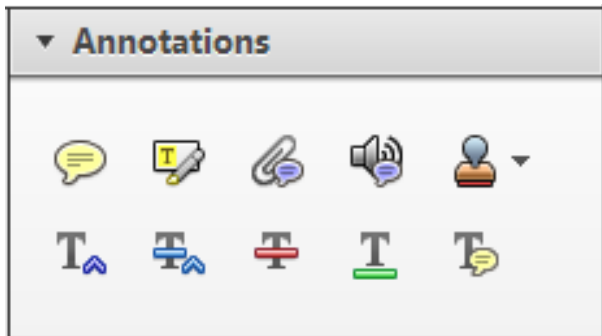

1. Replace (Ins) Tool - for replacing text.

Strikes a line through text and opens up a text box where replacement text can be entered.

\section{How to use it}

- Highlight a word or sentence.

- Click on the Replace (Ins) icon in the Annotations section.

- Type the replacement text into the blue box that appears.

Idard tramework for the analysis of $\mathrm{m}$ icy-Nevertheless, it also led to exog،

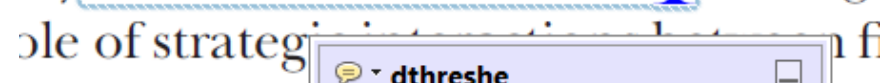
aber of comp 08/06/2011 15:58:17

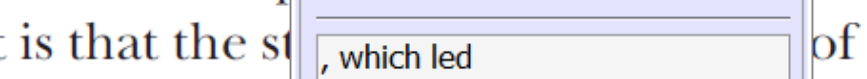
nain compo: be level, are exc nc

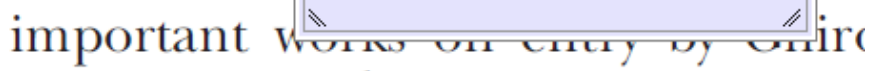
M heneferth) ${ }^{1}$ we anen the 'hlark $\mathrm{h}$

3. Add note to text Tool - for highlighting a section to be changed to bold or italic.

T Highlights text in yellow and opens up a text box where comments can be entered.

\section{How to use it}

- Highlight the relevant section of text.

- Click on the Add note to text icon in the Annotations section.

- Type instruction on what should be changed regarding the text into the yellow box that annears.

namic responses of mark ups ent with the VAR evidence

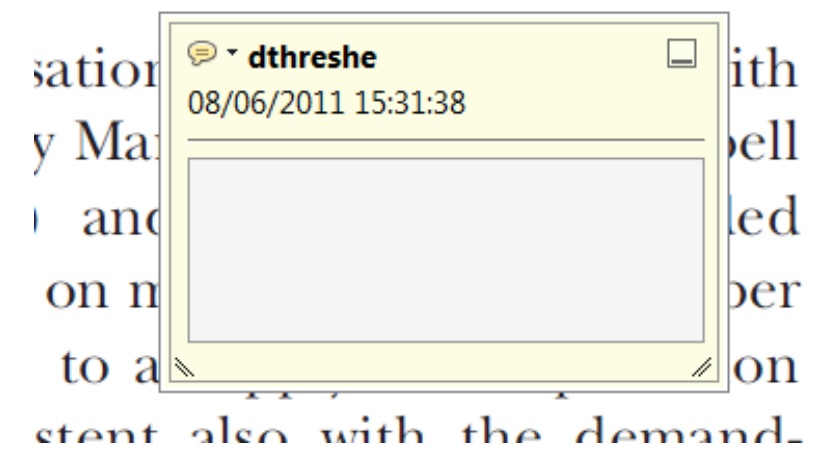

2. Strikethrough (Del) Tool - for deleting text.

Thikes a red line through text that is to be deleted.

\section{How to use it}

- Highlight a word or sentence.

- Click on the Strikethrough (Del) icon in the Annotations section.

there is no room tor extra prohts al c ups are zero and the number of ret) values are not determined by Blanchard and Kiyotaki (1987), rfect competition in general equilil ts of aggregate demand and supply lassical framework assuming monol eon an evorenois number of firms

\section{Add sticky note Tool - for making notes at} specific points in the text.

Marks a point in the proof where a comment needs to be highlighted.

\section{How to use it}

- Click on the Add sticky note icon in the Annotations section.

- Click at the point in the proof where the comment should be inserted.

- Type the comment into the yellow box that appears.

lallu allu suppiy silucks. hivst vi

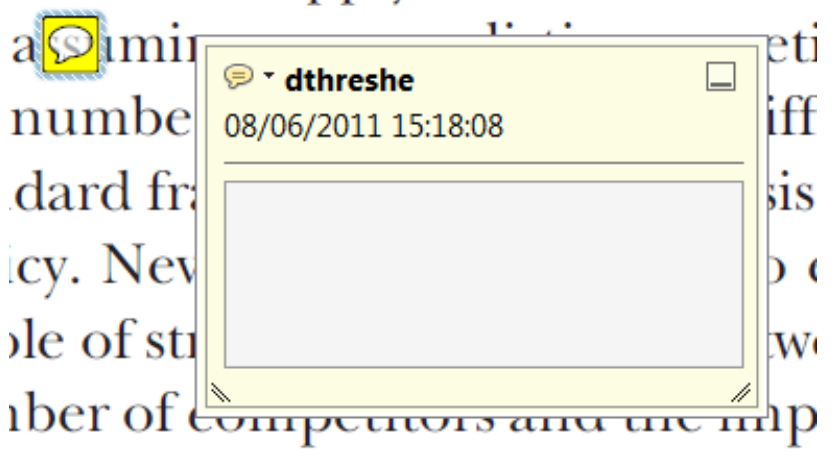

is that the structure of the secto 
5. Attach File Tool - for inserting large amounts of text or replacement figures.

Inserts an icon linking to the attached file in the appropriate pace in the text.

How to use it

- Click on the Attach File icon in the Annotations section.

- Click on the proof to where you'd like the attached file to be linked.

- Select the file to be attached from your computer or network.

- Select the colour and type of icon that will appear in the proof. Click OK.

E N D

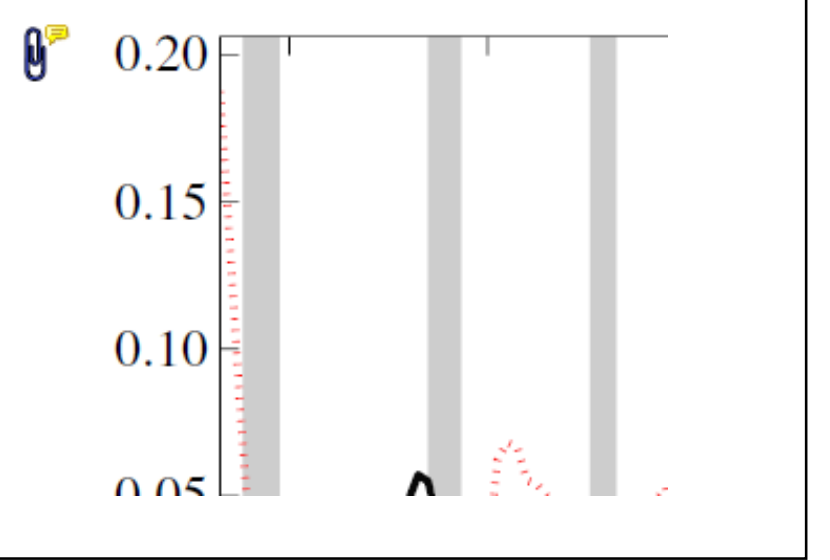

6. Add stamp Tool - for approving a proof if no corrections are required.

- Inserts a selected stamp onto an appropriate place in the proof

\section{How to use it}

- $\quad$ Click on the Add stamp icon in the Annotations section.

- $\quad$ Select the stamp you want to use. (The Approved stamp is usually available directly in the menu that appears).

- Click on the proof where you'd like the stamp to appear. (Where a proof is to be approved as it is, this would normally be on the first page).

of the Dusiness cycie, starting with the on perfect competition, constant ret

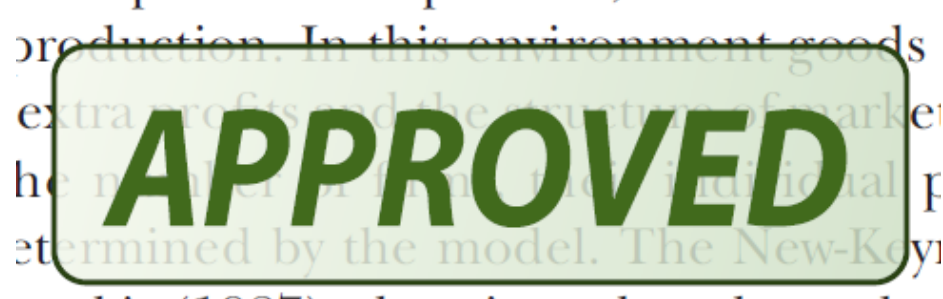

otaki (1987), has introduced produc general equilibrium models with nomin
- Drawing Markups

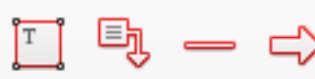

$0 \square \sqrt{6} D$

\section{How to use it}

- Click on one of the shapes in the Drawing Markups section.

- Click on the proof at the relevant point and draw the selected shape with the cursor.

- To add a comment to the drawn shape, move the cursor over the shape until an arrowhead appears.

- Double click on the shape and type any text in the red box that appears.
7. Drawing Markups Tools - for drawing shapes, lines and freeform annotations on proofs and commenting on these marks.

Allows shapes, lines and freeform annotations to be drawn on proofs and for comment to be made on these marks.

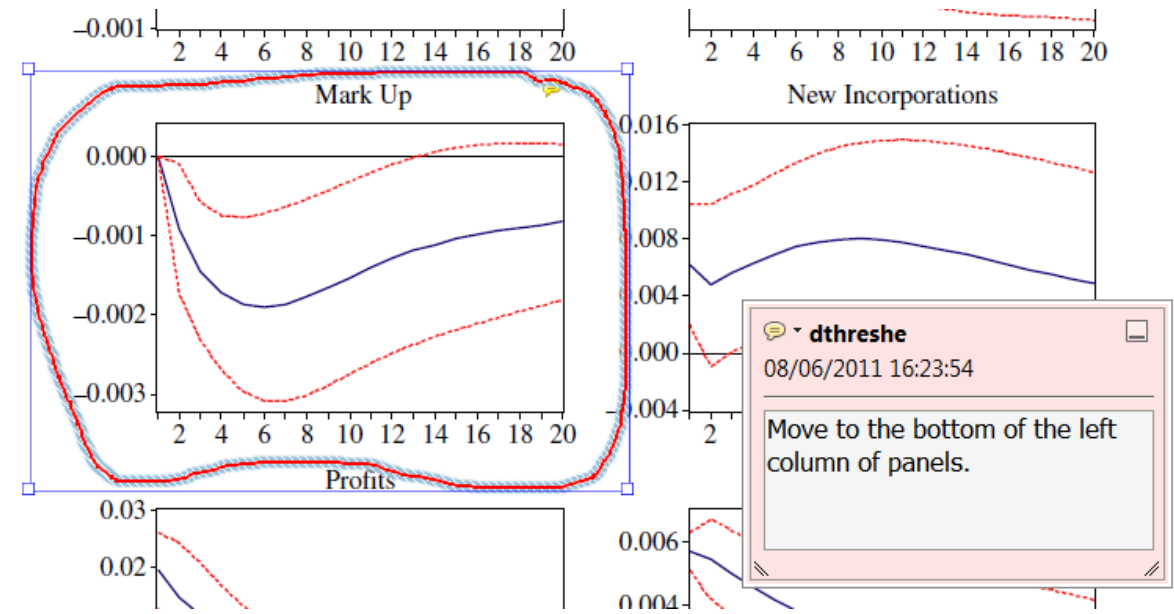

For further information on how to annotate proofs, click on the Help menu to reveal a list of further options:

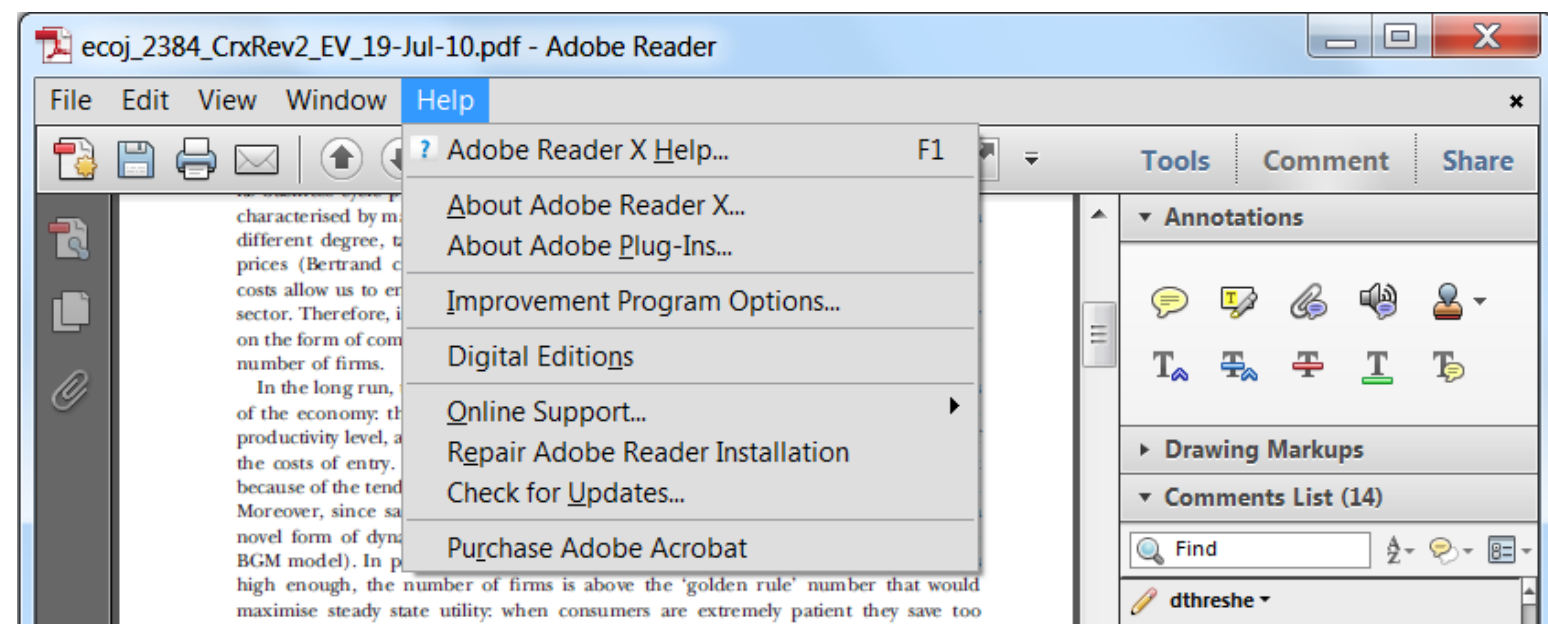

